\title{
Milliosmole per Kilogram
}

National Cancer Institute

\section{Source}

National Cancer Institute. Milliosmole per Kilogram. NCI Thesaurus. Code C67427.

A unit of osmotic strength of solution as a measure of concentration of osmotically active particles expressed in a number of milliosmoles of solute per kilogram of solvent. 